\title{
Amniotic fluid stem cell-based models to study the effects of gene mutations and toxicants on male germ cell formation
}

\begin{abstract}
Claudia Gundacker, Helmut Dolznig, Mario Mikula, Margit Rosner, Oliver Brandau and Markus Hengstschläger
Male infertility is a major public health issue predominantly caused by defects in germ cell development. In the past, studies on the genetic regulation of spermatogenesis as well as on negative environmental impacts have been hampered by the fact that human germ cell development is intractable to direct analysis in vivo. Compared with model organisms including mice, there are fundamental differences in the molecular processes of human germ cell development. Therefore, an in vitro model mimicking human sperm formation would be an extremely valuable research tool. In the recent past, both human embryonic stem (ES) cells and induced pluripotent stem (iPS) cells have been reported to harbour the potential to differentiate into primordial germ cells and gametes. We here discuss the possibility to use human amniotic fluid stem (AFS) cells as a biological model. Since their discovery in 2003, AFS cells have been characterized to differentiate into cells of all three germ layers, to be genomically stable, to have a high proliferative potential and to be non-tumourigenic. In addition, AFS cells are not subject of ethical concerns. In contrast to iPS cells, AFSs cells do not need ectopic induction of pluripotency, which is often associated with only imperfectly cleared epigenetic memory of the source cells. Since AFS cells can be derived from amniocentesis with disease-causing mutations and can be transfected with high efficiency, they could be used in probing gene functions for spermatogenesis and in screening for male reproductive toxicity.
\end{abstract}

Asian Journal of Andrology (2012) 14, 247-250; doi:10.1038/aja.2011.170; published online 9 January 2012

Keywords: amniotic fluid; human genetics; infertility; primordial germ cells; reproduction; spermatogenesis; stem cells; toxicity

\section{INTRODUCTION}

Spermatogenesis starts shortly after birth with gonocytes and so-called spermatogonial stem cells as founder populations. At puberty, mitotically dividing spermatogonial cells maintain the ability of selfrenewal and occupy niches in the seminiferous tubule in the testes. Early in spermatogenesis, these spermatogonial cells face the choice of self-renewal or differentiation. The end-product of spermatogenesis is the male gamete, called sperm. Germ cell development (male and female) is unique in generating haploid cells, which are responsible for the maintenance of the species. Errors in spermatogenesis can cause infertility, which is an increasing public health issue. On the one hand, it is well known that mutations and environmental toxicants can mediate severe negative effects on male germ cell development. On the other hand, for different reasons discussed below, the underlying molecular mechanisms still remain elusive. ${ }^{1-3}$

\section{THE RELEVANCE OF ANIMAL MODELS TO STUDY HUMAN GERM CELL DEVELOPMENT}

Our knowledge on the molecular processes controlling human germ cell formation is limited, mainly due to the inaccessibility of early stages of human development to experimentation. Exploration of the unknown causes of human infertility is hampered by many ethical and practical difficulties associated with the collection of relevant human tissue samples. Accordingly, most of our understanding on the regulation of infertility is based on epidemiological studies. ${ }^{4}$ Another reason for our limited knowledge on germ cell development in humans is that extrapolation of results obtained from animal models, such as mice, is not really possible (see the discussion in Ref. 5). In no other species, infertility caused by errors in germ cell formation and meiotic missegregation of chromosomes are nearly as common as in humans. ${ }^{6,7}$

Whereas women require two $\mathrm{X}$ chromosomes for oocyte development, mice are fertile with just a single $\mathrm{X}$ chromosome. ${ }^{8,9}$ The homology between human and mice of well known reproductive genes, such as STELLAR, GDF3 or NANOG, is very low with only $30 \%$ identity at the amino acid level in some cases. ${ }^{10,11}$ Regarding the topic of this review, it is of importance to consider that several Y chromosome genes, including the azoospermia-associated deleted in azoospermia (DAZ) genes, are absent in mice. ${ }^{12,13}$ Taken together, these fundamental differences in the molecular regulation of human germ cell development compared with model organisms underline the demand to establish stem cell-based approaches for the in vitro investigation of germ cell formation.

\section{EMBRYONIC STEM (ES) AND INDUCED PLURIPOTENT STEM (IPS) CELL-BASED MODELS TO STUDY MALE GERM CELL DEVELOPMENT IN VITRO}

Using in vitro differentiation approaches, mouse ES cells ${ }^{14-16}$ and human ES cells ${ }^{17-21}$ have been demonstrated to harbour the potential to form primordial germ cells and gametes. Recently, iPS cells derived 
from reprogramming of somatic cells also have been shown to differentiate into primordial germ cells and even to generate haploid germ cells. ${ }^{5,22-24}$ These pioneering studies allowed new important insights into the regulation of germ cell formation in vitro.

A variety of protocols have been established to promote germ cell formation from pluripotent stem cells. One potent approach is to isolate SSEA1-positive cells from embryoid bodies by immunomagnetic beads. Retinoic acid treatment for several days triggers rapid differentiation of ES cells, while stimulating proliferation of primordial germ cells. Retinoic acid treatment can therefore be used to distinguish between these two cell populations. ${ }^{25}$ Although meiosis is inefficient in embryoid bodies, it is possible to flow cytometrically isolate a small population of haploid cells (representing round spermatids) expressing FE-J1, which is specific for male meiotic germ cells ${ }^{16}$ (see also Figure 1). Spontaneous differentiation of pluripotent stem cells into primordial germ cells can also be induced by several days of cultivation in a medium containing bone morphogenetic proteins (BMP-4, BMP-7 and BMP-8b). The RNA binding protein VASA is specifically expressed in the germ cell lineage and is essential for germ cell formation. ${ }^{26}$ An elegant approach allowing flow cytometric isolation of germ cells after bone morphogenetic protein-induced differentiation is prior transfection of the pluripotent stem cells with a reporter system carrying GFP under the VASA promoter. Since spontaneous induction of meiosis is low, overexpression of genes of the $D A Z$ gene family can be performed to induce meiosis for haploid spermatids $^{5,27}$ (Figure 1). Finally, in mice it is possible to test the biological function of so-obtained haploid male gametes either by transplantation into busulfan-mediated sperm-depleted testes to check in vivo differentiation, or by intracytoplasmic injection into recipient oocytes to test whether this supports cleavage ${ }^{14-16}$ (Figure 1).

The approaches described above are readily available in vitro models mimicking human gamete development and are therefore extremely valuable research tools. Stem cell-based models have already been shown to be useful to investigate the role of specific genes for germ cell formation. ${ }^{27,28}$ It is well known that spermatogenesis is a complex biological process, which is particularly sensitive to environmental insults, such as toxicants, ${ }^{29}$ and stem cell-based in vitro models have already been used for reproductive toxicity screening. ${ }^{30,31}$

\section{AMNIOTIC FLUID STEM (AFS) CELLS COULD BE A USEFUL TOOL TO STUDY THE MOLECULAR REGULATION OF SPERMATOGENESIS AND THE EFFECTS OF TOXICANTS}

It is very likely that undifferentiated and differentiated cells of varying lineages and origins are present in amniotic fluid. In 2003, first evidence for the existence of human AFS cells was published describing a highly proliferative stem cell type in human amniotic fluid expressing the pluripotent marker Oct4. ${ }^{32}$ Meanwhile, many independent research groups have confirmed the existence of this $\mathrm{Oct} 4^{+} / \mathrm{c}-\mathrm{Kit}^{+}$ AFS cell type and have shown that these stem cells harbour the potential to differentiate, e.g. upon haematopoietic, neurogenic, osteogenic, chondrogenic, adipogenic, renal and hepatic lineages. Still, the precise origin of this stem cell type remains elusive. From their biological properties and their marker expression pattern, AFS cells appear to be closer to ES cells than e.g. to trophoblast cells. Most of the studies
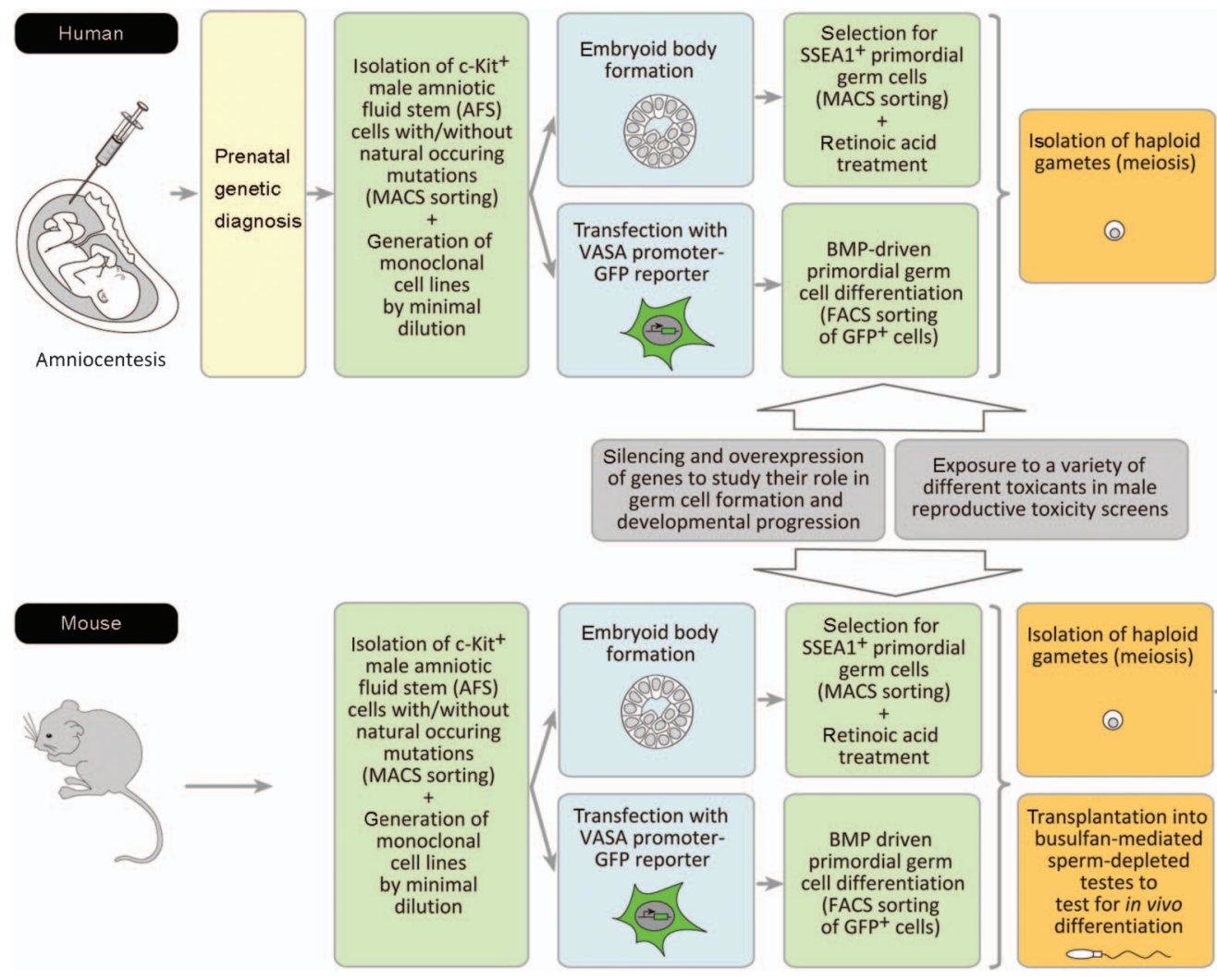

(FACS sorting of $\mathrm{GFP}^{+}$cells)
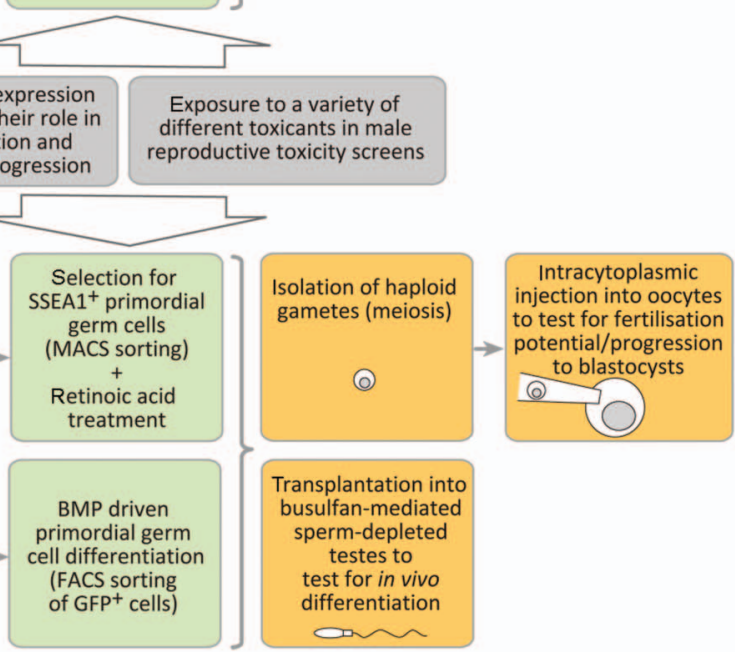

Figure 1 AFS cells as a model to study gene functions for spermatogenesis and to screen for male reproductive toxicity. Monoclonal AFS cell lines can be established from human and mouse amniotic fluid. These clonal stem cell lines can be tested for their potential to form primordial germ cells and male gametes. The effects of gene modulations and of a variety of different toxicants on spermatogenesis can be tested. For details, see the text. AFS, amniotic fluid stem; FACS, flow-activated cell sorting; GFP, green fluorescent protein; MACS, magnetic cell sorting; VASA, vasa. 
have been performed with AFS cells derived via amniocenteses, but there are also some data available with AFS cells isolated out of amniotic fluid at birth. ${ }^{33-48}$ It is now known that descending from one single AFS cell of this type, it is possible to induce both differentiation into cells of all three embryonic tissue types and embryoid body formation. These findings on the pluripotency of AFS cells were obtained using monoclonal cell lines generated via magnetic cell sorting (e.g., for c-Kit) and minimal dilution approaches from human amniocentesis samples. Monoclonal AFS cell lines can be cultivated in an undifferentiated status with high proliferation rate and without the need of feeder cells. ${ }^{38,41,49}$ In this article, we suggest to test the usability of human (and mouse) AFS cells as a model to study sperm cell development in vitro using the differentiation protocols described above for ES and iPS cells (Figure 1). We suggest to use the wellknown and widely used approach to isolate monoclonal Oct $4^{+} / \mathrm{c}-$ $\mathrm{Kit}^{+}$AFS cell lines. These AFS cell lines can be generated by minimal dilution starting expansion from one single stem cell. Several human cell lines of this kind exist and they exhibit identical behaviour. In a recent paper, ${ }^{49}$ we have compared three such monoclonal AFS cell lines proving that they are not heterogenous.

The generation of ES cell lines via destroying a human embryo raises a variety of ethical issues and furthermore ES cells are tumourigenic per se. ${ }^{50,51}$ In the case of iPS cells, the process of ectopic induction of pluripotency might somehow interfere with its usefulness as a biological model for germ cell formation. ${ }^{52-54}$ The same is true for the facts, that the epigenetic memory of the original differentiated state is not perfectly erased during reprogramming ${ }^{5,56}$ and that iPS cells have been reported to accumulate karyotypic abnormalities and gene mutations during propagation in culture. ${ }^{57-60}$ AFS very likely do not harbour accumulated somatic mutations, because they are primary cells of a very early stage of human development. Furthermore, monoclonal human AFS cell lines have been reported to maintain genome stability during expansion and do not induce tumour formation in severe combined immunodeficient mice. ${ }^{41,44,46,47,49,61,62}$

To analyse the genetic mechanisms of sperm cell development, it is of the highest relevance to use stem cell-based models, which allow the investigation of the consequences of a specific genetic aberration. ${ }^{63,64}$ One approach would be to use stem cells with natural occurring genetic aberrations, which are of relevance for human pathological phenotypes associated with infertility. ES cell lines with such disease-causing mutations can be generated using embryos, which in the course of in vitro fertilisation have been excluded from transfer into the uterus via preimplantation genetic diagnosis of single-gene disorders or structural and numerical chromosome aberrations. ${ }^{65,66}$ In the recent past, also a variety of iPS lines from single-gene disorders, chromosome syndromes and complex diseases have been generated and it would be of great interest to use iPS lines from infertile men as in vitro models for germ cell formation. ${ }^{67,68}$ However, the spectrum of usable ES cells with an inherited defect is limited, because in vitro fertilisation with preimplantation genetic diagnosis is only rarely applied. And whereas the usage of iPS cells derived from adults has the advantage that the detailed clinical history of the patient is known, one must take into account that such cells might have already accumulated other mutations, which might then interfere with the in vitro studies on spermatogenesis. ${ }^{64}$ Accordingly, here we want to suggest to generate AFS cell lines with prenatally diagnosed single-gene disorders, unbalanced segregated parental chromosome translocations, aneuploidies or de novo structural chromosomal aberrations. ${ }^{69}$ Such stem cell lines could then be useful for the exploration of the unknown genetic causes of male human infertility (Figure 1).
Another approach to obtain insights into the genetic regulation of male germ cell development is the modulation of gene expression in the here discussed stem cell-based models. As already described above, ES cell-based models have been successfully used to study the role of specific genes, such as DAZL, DAZ, BOULE or NANOS3, for germ cell formation. ${ }^{27,28}$ In this context, it is interesting to note that $D A Z L$ gene expression has been found in human amniotic fluid cell samples. ${ }^{70}$ However, it still must be clarified which cells within the amniotic fluid express this germ cell marker and whether this is of any physiological relevance. We here also want to suggest the usage of small interfering RNA-mediated knockdown of endogenous genes in human monoclonal AFS cells to investigate their roles during gamete formation. We have recently established a protocol for efficient small interfering RNA-mediated prolonged gene silencing in AFS cells allowing a 96\%-98\% downregulation of endogenous expressions over a time period of about 14 days. ${ }^{71}$ Spermatogenesis is a strictly regulated biological process, which is very sensitive to environmental toxicants, such as mercury and lead. Human are exposed to these ubiquitous environmental pollutants predominantly by ingestion of contaminated food and beverages and by inhalation of contaminated air. Both metals are known to accumulate in the human body and to target a variety of developmental processes. There is evidence that both metals can reduce male fertility by interfering with male germ cell development resulting in altered sperm density, motility and viability. ${ }^{29,72-74}$ ES cell-based approaches to study germ cell development have been shown to be useful tools for the direct examination of the effects of environmental toxicants on the molecular regulation of human germ cell formation. ${ }^{30,31}$ Very recently, we found that mercury and lead can affect the biological properties of human AFS cells. ${ }^{75}$ The differentiation of AFS cells into cell of the germ cell lineage would allow to investigate the role of these two toxicants on human male germ cell development, but also to screen additional substances for their toxic potential for spermatogenesis. AFS cell-based germ cell models may even be more useful to study the effects of toxicants than that of mutations, since in vitro manipulations might induce other interfering mutations that may complicate the investigation of the original question. The efficiency of differentiation from ES or iPS cells into haploid male germ cells is generally reported to be low. ${ }^{14-24}$ Although there is no evidence for the speculation that this efficiency might be higher using AFS cells, to our opinion, the here reviewed knowledge warrants testing this new stem cell type for their usability for the in vitro investigation of sperm production (Figure 1).

\section{COMPETING FINANCIAL INTERESTS}

The authors declare no competing financial interest.

1 Sassone-Corsi P. Stem cells of the germline: the specialized facets of their differentiation program. Cell Cycle 2008; 7: 3491-2.

2 Phillips BT, Gassei K, Orwig KE. Spermatogonial stem cell regulation and spermatogenesis. Philos Trans R Soc Lond B Biol Sci 2010; 365: 1663-78.

3 Yoshida S. Stem cells in mammalian spermatogenesis. Dev Growth Differ 2010; 52 : 311-7.

4 Kee K, Pera RA, Turek PJ. Testicular germline stem cells. Nat Rev Urol 2010; 7: 94-100.

5 Panula S, Medrano JV, Kee K, Bergström R, Nguyen HN et al. Human germ cell differentiation from fetal- and adult-derived induced pluripotent stem cells. Hum Mol Genet 2011; 20: 752-62.

6 Menken J, Larsen U. Estimating the incidence and prevalence and analyzing the correlates of infertility and sterility. Ann NY Acad Sci 1994; 709: 249-65.

7 Hunt PA, Hassold TJ. Sex matters in meiosis. Science 2002; 296: 2181-3.

8 Zinn AR, Page DC, Fisher EM. Turner syndrome: the case of the missing sex chromosome. Trends Genet 1993; 9: 90-3.

9 Davison RM, Davis CJ, Conway GS. The $X$ chromosome and ovarian failure. Clin Endocrinol 1999; 51: 673-9. 
10 Saitou M, Barton SC, Surani MA. A molecular programme for the specification of germ cell fate in mice. Nature 2002; 418: 293-300.

11 Clark AT, Rodriguez RT, Bodnar MS, Abeyta MJ, Cedars MI et al. Human STELLAR, NANOG, and GDF3 genes are expressed in pluripotent cells and map to chromosome 12p13, a hotspot for teratocarcinoma. Stem Cells 2004; 22: 169-79.

12 Reijo R, Lee TY, Salo P, Alagappan R, Brown LG et al. Diverse spermatogenic defects in humans caused by $Y$ chromosome deletions encompassing a novel RNA-binding protein gene. Nat Genet 1995; 10: 383-93.

13 Skaletsky H, Kuroda-Kawaguchi T, Minx PJ, Cordum HS, Hillier L et al. The malespecific region of the human $Y$ chromosome is a mosaic of discrete sequence classes. Nature 2003; 423: 825-37.

14 Hübner K, Fuhrmann G, Christenson LK, Kehler J, Reinbold R et al. Derivation of oocytes from mouse embryonic stem cells. Science 2003; 300: 1251-6.

15 Toyooka Y, Tsunekawa N, Akasu R, Noce T. Embryonic stem cells can form germ cells in vitro. Proc Natl Acad Sci USA 2003; 100: 11457-62.

16 Geijsen N, Horoschak M, Kim K, Gribnau J, Eggan K et al. Derivation of embryonic germ cells and male gametes from embryonic stem cells. Nature 2004; 427: 148-54.

17 Clark AT, Bodnar MS, Fox M, Rodriquez RT, Abeyta MJ et al. Spontaneous differentiation of germ cells from human embryonic stem cells in vitro. Hum $\mathrm{Mol}$ Genet 2004; 13: 727-39.

18 Kee K, Gonsalves JM, Clark AT, Pera RA. Bone morphogenetic proteins induce germ cell differentiation from human embryonic stem cells. Stem Cells Dev 2006; 15: 831-7.

19 Tilgner K, Atkinson SP, Golebiewska A, Stojkovic M, Lako M et al. Isolation of primordial germ cells from differentiating human embryonic stem cells. Stem Cells 2008; 26: 3075-85.

20 Bucay N, Yebra M, Cirulli V, Afrikanova I, Kaido T et al. A novel approach for the derivation of putative primordial germ cells and Sertoli cells from human embryonic stem cells. Stem Cells 2009; 27: 68-77.

21 Aflatoonian B, Ruban L, Jones M, Aflatoonian R, Fazeli A et al. In vitro post-meiotic germ cell development from human embryonic stem cells. Hum Reprod 2009; 24: 3150-9.

22 Park TS, Galic Z, Conway AE, Lindgren A, van Handel BJ et al. Derivation of primordial germ cells from human embryonic and induced pluripotent stem cells is significantly improved by coculture with human fetal gonadal cells. Stem Cells 2009; 27: 783-95.

23 Imamura M, Aoi T, Tokumasu A, Mise N, Abe K et al. Induction of primordial germ cells from mouse induced pluripotent stem cells derived from adult hepatocytes. Mol Reprod Dev 2010; 77: 802-11.

24 Hayashi K, Ohta H, Kurimoto K, Aramaki S, Saitou M. Reconstitution of the mouse germ cell specification pathway in culture by pluripotent stem cells. Cell 2011; 146: 519-32.

25 Koshimizu U, Watanabe M, Nakatsuji N. Retinoic acid is a potent growth activator of mouse primordial germ cells in vitro. Dev Biol 1995; 168: 683-5.

26 Castrillon DH, Quade BJ, Wang TY, Quigley C, Crum CP. The human VASA gene is specifically expressed in the germ cell lineage. Proc Natl Acad Sci USA 2000; 97: 9585-90.

27 Kee K, Angeles VT, Flores M, Nguyen HN, Reijo Pera RA. Human DAZL, DAZ and $B O U L E$ genes modulate primordial germ-cell and haploid gamete formation. Nature 2009; 462: 222-5.

28 Julaton VT, Reijo Pera RA. NANOS3 function in human germ cell development. Hum Mol Genet 2011; 20: 2238-50.

29 Lucas B, Fields C, Hofmann MC. Signaling pathways in spermatogonial stem cells and their disruption by toxicants. Birth Defects Res C Embryo Today 2009; 87: 35-42.

30 Krtolica A, Giritharan G. Use of human embryonic stem cell-based models for male reproductive toxicity screening. Syst Biol Reprod Med 2010; 56: 213-21.

31 Kee K, Flores M, Cedars MI, Reijo Pera RA. Human primordial germ cell formation is diminished by exposure to environmental toxicants acting through the AHR signaling pathway. Toxicol Sci 2010; 117: 218-24.

32 Prusa A, Marton E, Rosner M, Bernaschek G, Hengstschläger M. Oct-4 expressing cells in human amniotic fluid: a new source for stem cell research? Hum Reprod 2003; 18: 1489-93.

33 in't Anker PS, Scherjon SA, Kleijburg-van der Keur C, Noort WA, Claas FH et al. Amniotic fluid as a novel source of mesenchymal stem cells for therapeutic transplantation. Blood 2003; 102: 1548-9.

34 Prusa AR, Marton E, Rosner M, Freilinger A, Bernachek G et al. Stem cell marker expression in human trisomy 21 amniotic fluid cells and trophoblasts. J Neural Transm 2003; 67: 235-42.

35 Tsai MS, Lee JL, Chang YJ, Hwang SM. Isolation of human multipotent mesenchymal stem cells from second-trimester amniotic fluid using a novel two-stage culture protocol. Hum Reprod 2004; 19: 1450-6.

36 Prusa AR, Marton E, Rosner M, Bettelheim D, Lubec G et al. Neurogenic cells in human amniotic fluid. Am J Obstet Gynecol 2004; 191: 309-14.

37 Karlmark KR, Freilinger A, Marton E, Rosner M, Lubec G et al. Activation of Oct-4 and Rex-1 promoters in human amniotic fluid cells. Int J Mol Med 2005; 16: 987-92.

38 Tsai MS, Hwang SM, Tsai YL, Cheng FC, Lee JL et al. Clonal amniotic fluid-derived stem cells express characteristics of both mesenchymal and neural stem cells. Biol Reprod 2006; 74: 545-51.

39 Bossolasco P, Montemurro T, Cova L, Zangrossi S, Calzarossa C et al. Molecular and phenotypic characterization of human amniotic fluid cells and their differentiation potential. Cell Res 2006; 16: 329-36.

$40 \mathrm{Kim} \mathrm{J}$, Lee Y, Kim H, Hwang KJ, Kwon $\mathrm{HC}$ et al. Human amniotic fluid-derived stem cells have characteristics of multipotent stem cells. Cell Prolif 2007; 40: 75-90.

41 De Coppi P, Bartsch G, Siddiqui MM, Xu T, Santos TX et al. Isolation of amniotic stem cell lines with potential for therapy. Nat Biotechnol 2007; 25: 100-6.

42 Kolambkar YM, Peister A, Soker S, Atala A, Guldberg RE. Chondrogenic differentiation of amniotic fluid-derived stem cells. J Mol Hist 2007; 38: 405-13.
43 Ditadi A, de Coppi P, Picone O, Gautreau L, Smati R et al. Human and murine amniotic C-Kit ${ }^{+}$Lin $^{-}$cells display hematopoietic activity. Blood 2009; 113: 3953-60.

44 Perin L, Giuliani S, Jin D, Sedrakyan S, Carraro G et al. Renal differentiation of amniotic fluid stem cells. Cell Prolif 2007; 40: 936-48.

45 Siegel N, Valli A, Fuchs C, Rosner M, Hengstschläger M. Induction of mesenchymal/ epithelial marker expression in human amniotic fluid stem cells. RBM Online 2009; 19: 838-46.

46 Siegel N, Rosner M, Unbekandt M, Fuchs C, Slabina N et al. Contribution of human amniotic fluid stem cells to renal tissue formation depends on mTOR. Hum Mol Genet 2010; 19: 3320-31.

47 Perin L, Sedrakyan S, Giuliani S, DaSacco S, Carraro G et al. Protective effect of human amniotic fluid stem cells in an immunodeficient mouse model of acute tubular necrosis. PLOS ONE 2010; 5: 1-16

48 Hauser PV, DeFazio R, Bruno S, Sdei S, Grange $C$ et al. Stem cells derived from human amniotic fluid contribute to acute kidney injury recovery. Am J Pathol 2010; 177: 2011-21.

49 Valli A, Rosner M, Fuchs C, Siegel N, Bishop CE et al. Embryoid body formation of human amniotic fluid stem cells depends on mTOR. Oncogene 2010: 29: 966-77.

50 Thomson JA, Itskovitz-Eldor J, Shapiro SS, Waknitz MA, Swiergiel JJ et al. Embryonic stem cell lines derived from human blastocysts. Science 1998; 282: 1145-7.

$51 \mathrm{Kamm}$ FM. Ethical issues in using and not using embryonic stem cells. Stem Cell Rev 2005; 1: 325-30

52 Takahashi K, Yamanaka S. Induction of pluripotent stem cells from mouse embryonic and adult fibroblast cultures by defined factors. Cell 2006; 126: 663-76.

53 Stadtfeld M, Hochedlinger K. Induced pluripotency: history, mechanisms, and applications. Genes Dev 2010; 24: 2239-63.

54 Mattis V, Svendsen CN. Induced pluripotent stem cells: a new revolution for clinical neurology? Lancet Neurol 2011; 10: 383-94.

55 Kim K, Doi A, Wen B, Ng K, Zhao R et al. Epigenetic memory in induced pluripotent stem cells. Nature 2010; 467: 285-90.

56 Stadtfeld M, Apostolou E, Akutsu H, Fukuda A, Follett P et al. Aberrant silencing of imprinted genes on chromosome $12 \mathrm{qF} 1$ in mouse induced pluripotent stem cells. Nature 2010; 465: 175-81.

57 Laurent LC, Ulitsky I, Slavin I, Tran H, Schork A et al. Dynamic changes in the copy number of pluripotency and cell proliferation genes in human ESCs and iPSCs during reprogramming and time in culture. Cell Stem Cell 2011; 8: 106-18.

58 Mayshar Y, Ben-David U, Lavon N, Biancotti JC, Yakir B et al. Identification and classification of chromosomal aberrations in human induced pluripotent stem cells. Cell Stem Cell 2010; 7: 521-31.

59 Gore A, Li Z, Fung HL, Young JE, Agarwal S et al. Somatic coding mutations in human induced pluripotent stem cells. Nature 2011; 471: 63-7.

60 Pasi CE, Dereli-Öz A, Negrini S, Friedli M, Fragola G et al. Genomic instability in induced stem cells. Cell Death Differ 2011; 18: 745-53.

61 Pappa KI, Anagnou NP. Novel sources of fetal stem cells: where do they fit on the developmental continuum? Regen Med 2009; 4: 423-33.

62 Dobreva P, Pereira PN, Deprest J, Zwijsen A. On the origin of amniotic stem cells: of mice and men. Int J Dev Biol 2010; 54: 761-77.

63 Zhu H, Lensch WM, Cahan P, Daley GQ. Investigating monogenic and complex diseases with pluripotent stem cells. Nat Rev Genet 2011; 12: 266-75.

64 Rosner M, Dolznig H, Schipany K, Mikula M, Brandau O et al. Human amniotic fluid stem cells as a model for functional studies of genes involved in human genetic diseases or oncogenesis. Oncotarget 2011; 2: 705-12.

65 Verlinsky Y, Strelchenko N, Kukharenko V, Rechitsky S, Verlinsky 0 et al. Human embryonic stem cell lines with genetic disorders. Reprod Biochem Online 2004; 10: $105-10$.

66 Ben-Yosef D, Malcov M, Eiges R. PGD-derived human embryonic stem cell lines as a powerful tool for the study of human genetic disorders. Mol Cell Endocrinol 2008; 282: 153-8.

67 Dimos JT, Rodolfa KT, Niakan KK, Weisenthal LM, Mitsumoto H et al. Induced pluripotent stem cells generated from patients with ALS can be differentiated into motor neurons. Science 2008; 321: 1218-21.

68 Park IH, Arora N, Huo H, Maherali N, Ahfeldt T et al. Disease-specific induced pluripotent stem cells. Cell 2008; 134: 877-86.

69 Raymond FL, Whittaker J, Jenkins L, Lench N, Chitty LS. Molecular prenatal diagnosis: the impact of modern technologies. Prenat Diagn 2010; 30: 674-81.

70 Stefanidis K, Loutradis D, Koumbi L, Anastasiadou V, Dinopoulou V et al. Deleted in Azoospermia-Like ( $D A Z L)$ gene-expressing cells in human amniotic fluid: a new source for germ cells research? Fertil Steril 2008; 90: 798-804.

71 Rosner M, Siegel N, Fuchs C, Slabina N, Dolznig H et al. Efficient siRNA-mediated prolonged gene silencing in human amniotic fluid stem cells. Nat Protoc 2010; 5: 1081-95.

72 Apostoli P, Kiss P, Porru S, Bonde JP, Vanhoorne M. Male reproductive toxicity of lead in animals and humans. ASCLEPIOS Study Group. Occup Environ Med 1998; 55: 364-74.

73 Choy CM, Lam CW, Cheung LT, Briton-Jones CM, Cheung LP et al. Infertility, blood mercury concentrations and dietary seafood consumption: a case-control study. BJOG 2002; 109: 1121-5.

74 Gundacker C, Gencik M, Hengstschläger M. The relevance of the individual genetic background for the toxicokinetics of two significant neurodevelopmental toxicants: mercury and lead. Mutat Res 2010; 705: 130-40.

75 Gundacker C, Scheinast M, Damjanovic L, Fuchs C, Rosner M et al. Proliferation potential of human amniotic fluid stem cells differently responds to mercury and lead exposure. Amino Acids; e-pub ahead of print 19 November 2011; doi: 10.1007/s00726-011-1154-1. 